\title{
Magnetic Applications to Subsurface and Groundwater Investigations: A Case Study from Wadi El Assiuti, Egypt
}

\author{
Ahmed Mohamed* ${ }^{\circledR}$, Elsayed M. Abu El Ella \\ Geology Department, Faculty of Science, Assiut University, Assiut, Egypt \\ Email: ^ahmed.mohamed.aun@gmail.com, ahmedmohamed@aun.edu.eg
}

How to cite this paper: Mohamed, A. and Abu El Ella, E.M. (2021) Magnetic Applications to Subsurface and Groundwater Investigations: A Case Study from Wadi El Assiuti, Egypt. International Journal of Geosciences, 12, 77-101.

https://doi.org/10.4236/ijg.2021.122006

Received: January 9, 2021

Accepted: February 2, 2021

Published: February 8, 2021

Copyright $\odot 2021$ by author(s) and Scientific Research Publishing Inc. This work is licensed under the Creative Commons Attribution International License (CC BY 4.0).

http://creativecommons.org/licenses/by/4.0/

\begin{abstract}
Wadi El Assiuti represents a promising area for agricultural development and building new communities far from the overpopulated areas in the Nile Valley. An integrated approach of satellite-based data and geophysical data with borehole data was used for defining the area of interest, the sediment thickness, delineating the subsurface structures, and mapping the depth to the basement rocks, and defining the groundwater aquifers. Findings are: 1) Dramatic changes are detected in the anthropogenic activities at the entrance area of the wadi, making stress and heavy exploitation of the groundwater resources. However, the central and northeastern regions show no development; 2) Several structural trends in the directions of NNW, NW, NE, and $\mathrm{E}-\mathrm{W}$ are cutting the basement rocks and sedimentary cover; 3 ) The depth to the basement rocks is increasing eastward from $\sim 2.24 \mathrm{~km}$ to $\sim 4.84 \mathrm{~km} ; 4$ ) Three groundwater-bearing reservoirs are represented by the shallow Quaternary, the fractured limestone, and the deep Nubian sandstone aquifers; 5) The deep-seated faults are affecting the area and rising groundwater from the deeper Nubian aquifer along its sub-vertical trend; and 6) The results are informative and used to define the suitable sites for water well drilling.
\end{abstract}

\section{Keywords}

Wadi El Assiuti, Aeromagnetic Data, Change Detection, Structural Trends, Sediment Thickness, Groundwater Aquifers

\section{Introduction}

Wadi El Assiuti is one of the most important wadis in middle Egypt, with a dry drainage basin, whose main stream reaches $\sim 186 \mathrm{~km}$ in length [1]. Its watershed 
basin (Figure 1) is located directly east of the Nile River between longitudes $31^{\circ} 12^{\prime} \mathrm{E}$ and $32^{\circ} 30^{\prime} \mathrm{E}$, and latitudes $27^{\circ} 00^{\prime} \mathrm{N}$ and $27^{\circ} 48^{\prime} \mathrm{N}$. It is a natural extension of Assiut Governorate in the Eastern Desert due to its groundwater potentialities and uncultivated soils. The catchment basin of this wadi is located entirely in the Mazza limestone plateau. Wadi El Assiuti (Figure 1) is a desert area, except for some parts of urbanization, and very small agricultural parts, which are located close to the entrance of the wadi. The increase of land reclamations for different agricultural activities and vast growth of new settlements (e.g. new Assiut city) in Assiut governorate has led to a search for new groundwater resources, necessary for sustainable development of the agricultural expansion.

One of the major plans of Egypt 2030 is to cultivate new 1.5 million Feddans in the desert to save foods and jobs for people and to build new communities far

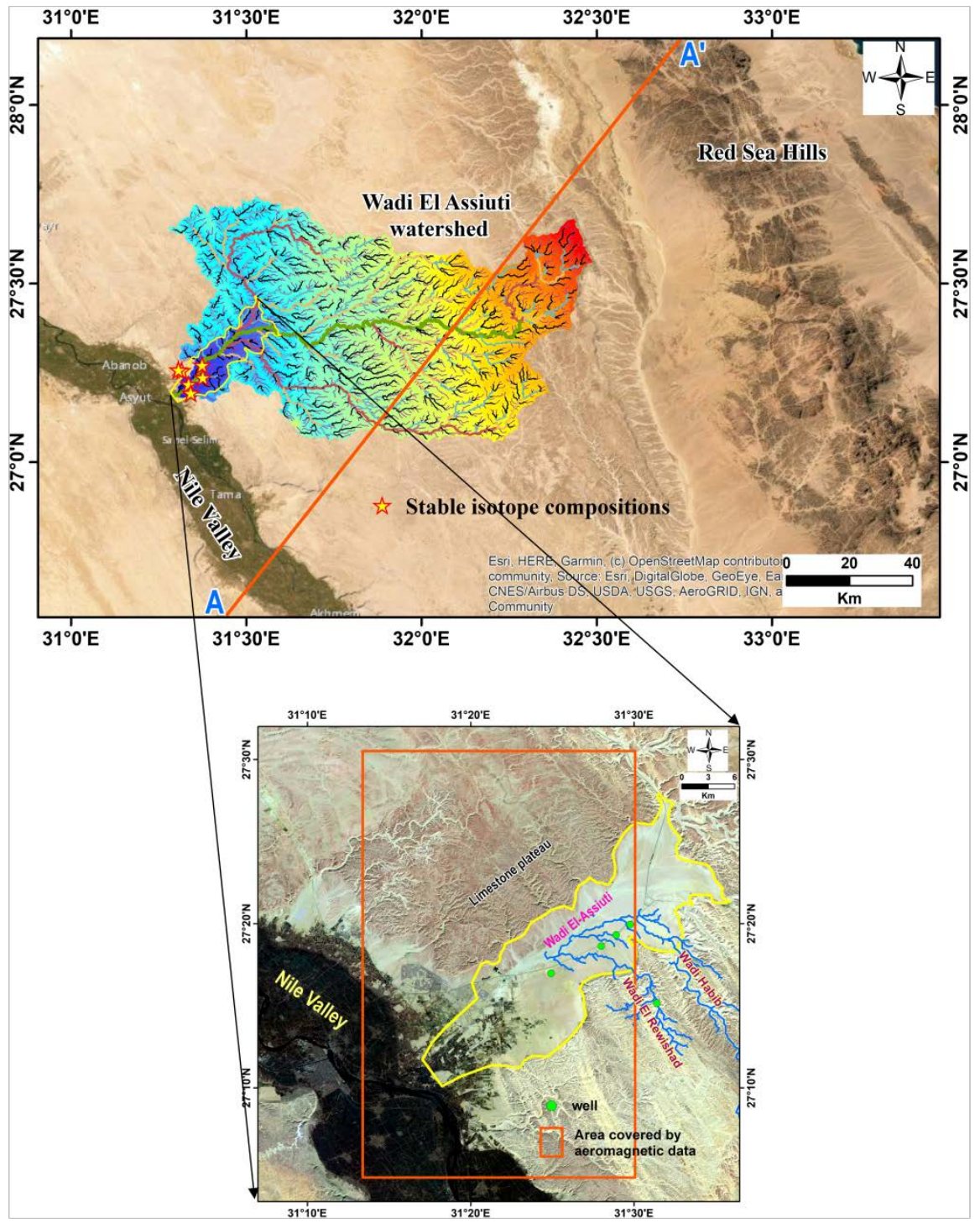

Figure 1. Showing the location of Wadi El Assiuti watershed. Stream networks extracted over the watershed of Wadi El Assiuti. It shows also the available aeromagnetic data; and the locations of isotopically $(\mathrm{O}, \mathrm{H})$ analyzed groundwater samples [2]. 
from the overpopulated areas in the Nile valley. Wadi El Assiuti represents one of the most promising desert areas for sustainable development. Shallow groundwater resources in the wadi have been used for agricultural purposes for more than 20 years; however, the heavy exploitation is leading to a decline in the groundwater table. As a consequence, extensive efforts and resources are required to explore the occurrence of groundwater in the different aquifers to sustain the development activities in the investigated areas. Moreover, suitable soils for agricultural expansion are common. The magnetic data are used to delineate the structural trends of the subsurface and the depth to the basement rocks. It is widely used in many areas [3] [4] [5]. These structural trends and the depth to the basement rocks may affect the groundwater-bearing reservoirs.

Many geological studies have been carried out by many researchers and companies on different regions of the Eastern Desert, the Nile Valley, and the entrance of Wadi El Assiuti [6]-[12]. However, No detailed geophysical studies have been conducted on the uncultivated area of the wadi.

The aim of the current work is to evaluate the occurrence of groundwater resources and to delineate the structural trends and the depth to the basement rocks affecting the groundwater in the studied area of Wadi El Assiuti, based on airborne magnetic data. The results of the geophysical data were integrated with the available borehole data to get better results and interpretations. Furthermore, this study was aimed to determine the more preferable place/places to drill new production wells in the study area.

\section{Litho-Stratigraphy}

The lithostratigraphic units [6] [7] (Figure 2) in the area of the wadi are discussed in descending order as below:

1) Recent to sub-recent alluvial sediments, represented by sandy deposits and wadi filling.

2) Pleistocene sediments are traced and mapped into the following sediments:

a) Recent to sub recent alluvial cover;

b) Neonile silts and clays;

c) Prenile sands;

d) Paleonile/protonile sediments, represented by the Armant and Issawia Formations; and

e) Pliocene (Paleonile) sediments of interbedded red-brown clays and thin fine-grained sand and silt laminae.

3) Lower Eocene carbonate rocks.

\section{Material and Methods}

\subsection{Satellite-Based Data}

Shuttle Radar Topography Mission (SRTM) images with a $90 \mathrm{~m}$ resolution were utilized to construct a Digital Elevation Model (DEM) for the Wadi El Assiuti watershed. The DEM was used for delineation of the basin and the stream networks 


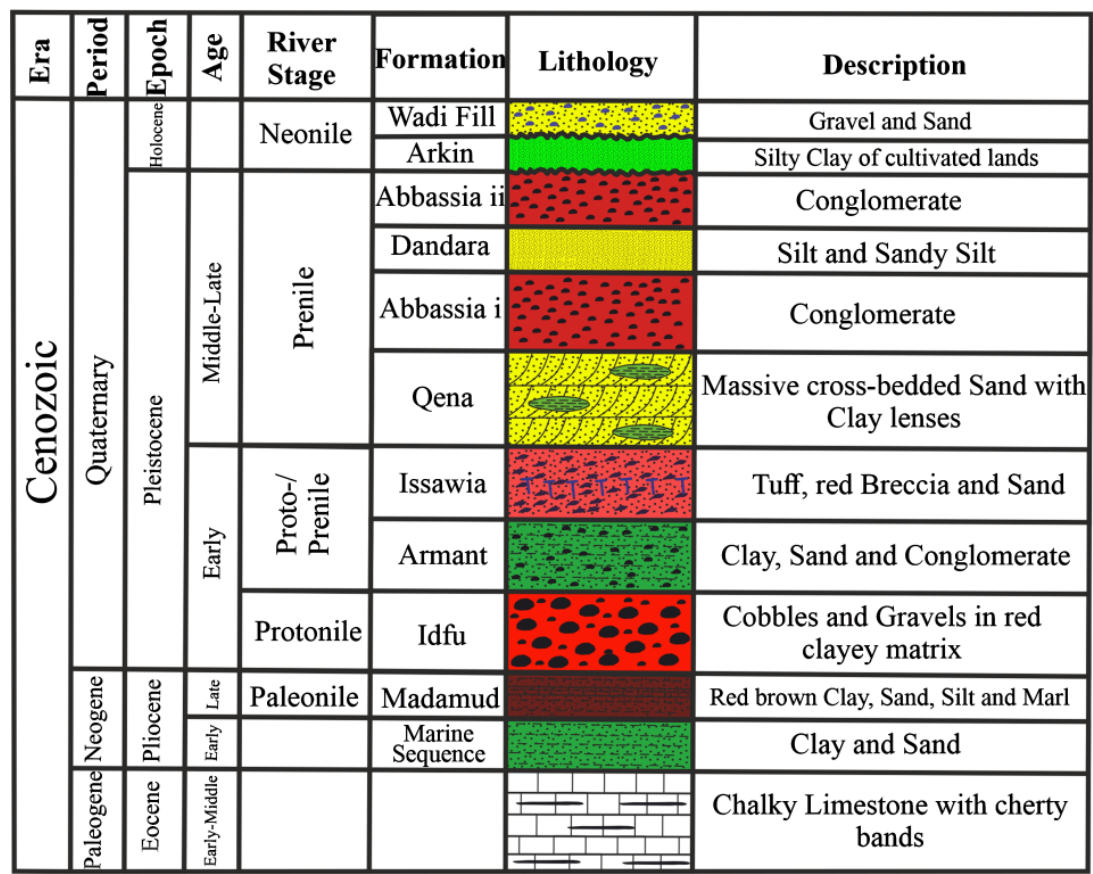

Figure 2. Composite stratigraphic cross section of the study area [6] [7].

in the area (Figure 1). Multi-temporal satellite images of Landsat 7 and 8 datasets are used in the current study to detect the changes in the land use/land cover (Figure 3). Landsat 7 Enhanced Thematic Mapper Plus images, acquired in 2001 and 2011 for Path 176 and Row 41, covering the study area, have been radiometrically and geometrically corrected, with spatial resolutions of $30 * 30$ and $15 *$ $15 \mathrm{~m}$ for six multispectral and one panchromatic band, respectively. Landsat 8 Operational Land Imager images, acquired in 2019 for Path 176 and Row 41, covering the Wadi El Assiuti, have been radiometrically and geometrically corrected, with spatial resolutions of $30 * 30$ and $15 * 15 \mathrm{~m}$ for eight multispectral and one panchromatic band, respectively. A 742 (Red Green Blue) image (Figure 3 ) is used each time to detect the changes in the wadi and to define the uncultivated areas.

\subsection{Aeromagnetic Data}

The aeromagnetic data, collected by the Western Geophysical Company of America (1983), are used in the current study. The total magnetic intensity (TMI) data were subjected to different processing techniques. These techniques include the reduction to the pole (RTP) that is carried out to remove the anomaly asymmetry caused by inclination. The average magnetic inclination of $38.75^{\circ}$ and declination of $1.90^{\circ}$ were applied. It relocates the magnetic anomalies above the causative bodies assuming that the remnant magnetism is small compared to the induced magnetism. Upward continuation, horizontal, and tilt derivative techniques are used to delineate the surface and subsurface structural trends affecting the study area and the groundwater. A 2D magnetic modeling was carried out to estimate the depth to the basement rocks. The processing and analysis of 
the aeromagnetic data were done using the Geosoft program [13]. The TMI map is shown in Figure 4 with values varying between 41,593.4 and 41,812.1 nT.

\subsection{Borehole Data}

The available borehole data (Figure 1) were used to study the groundwater aquifers in the area.

\section{Data Interpretation}

\subsection{Land Use/Land Cover}

Remote sensing data have many different applications in the change detection
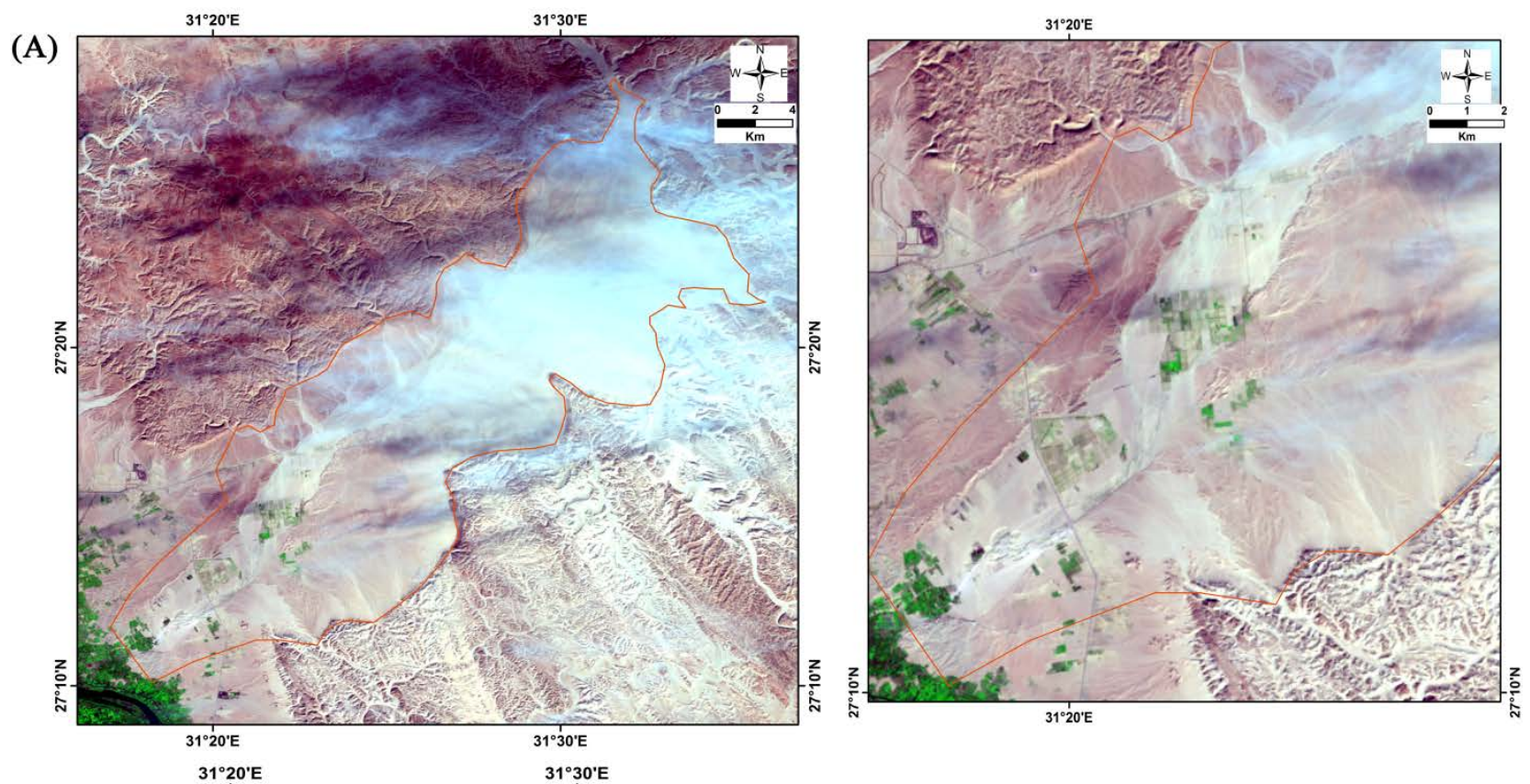

(B)
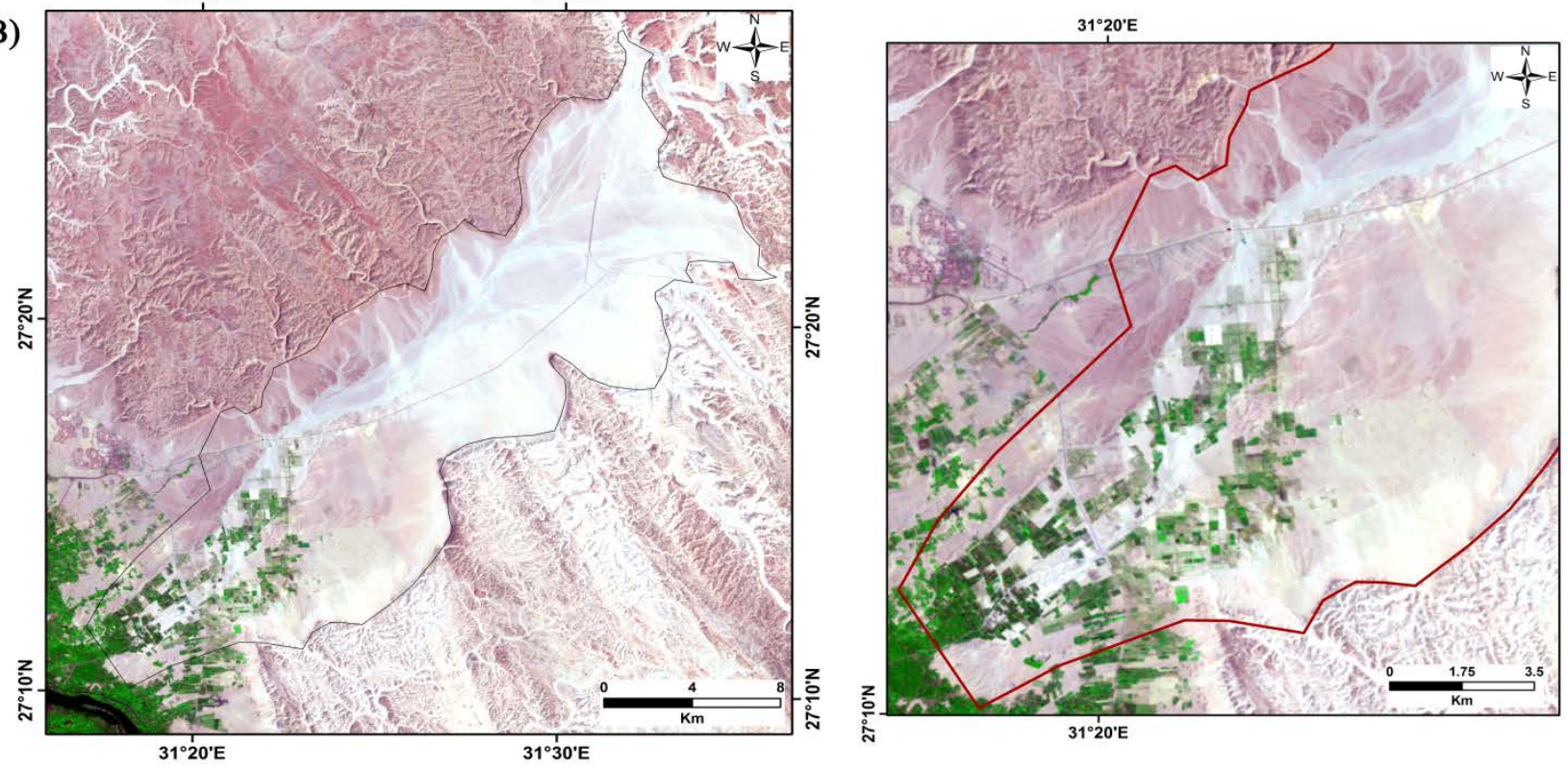


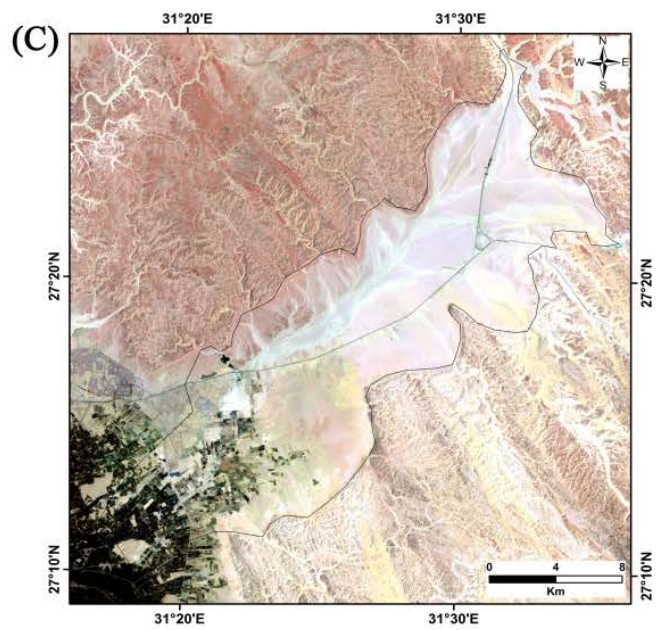

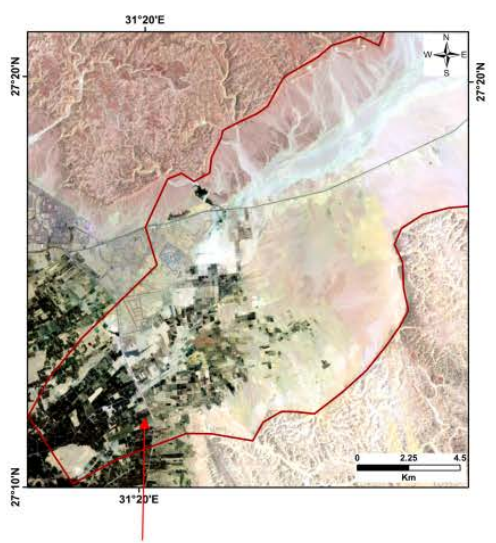

Cultivated land

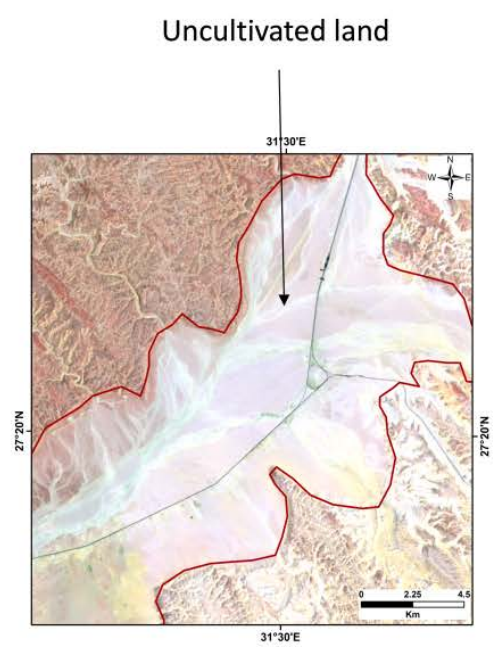

Figure 3. Landsat 742 (RGB) images showing the Land use changes in the years 2001 (A), 2011 (B) and 2019 (C).

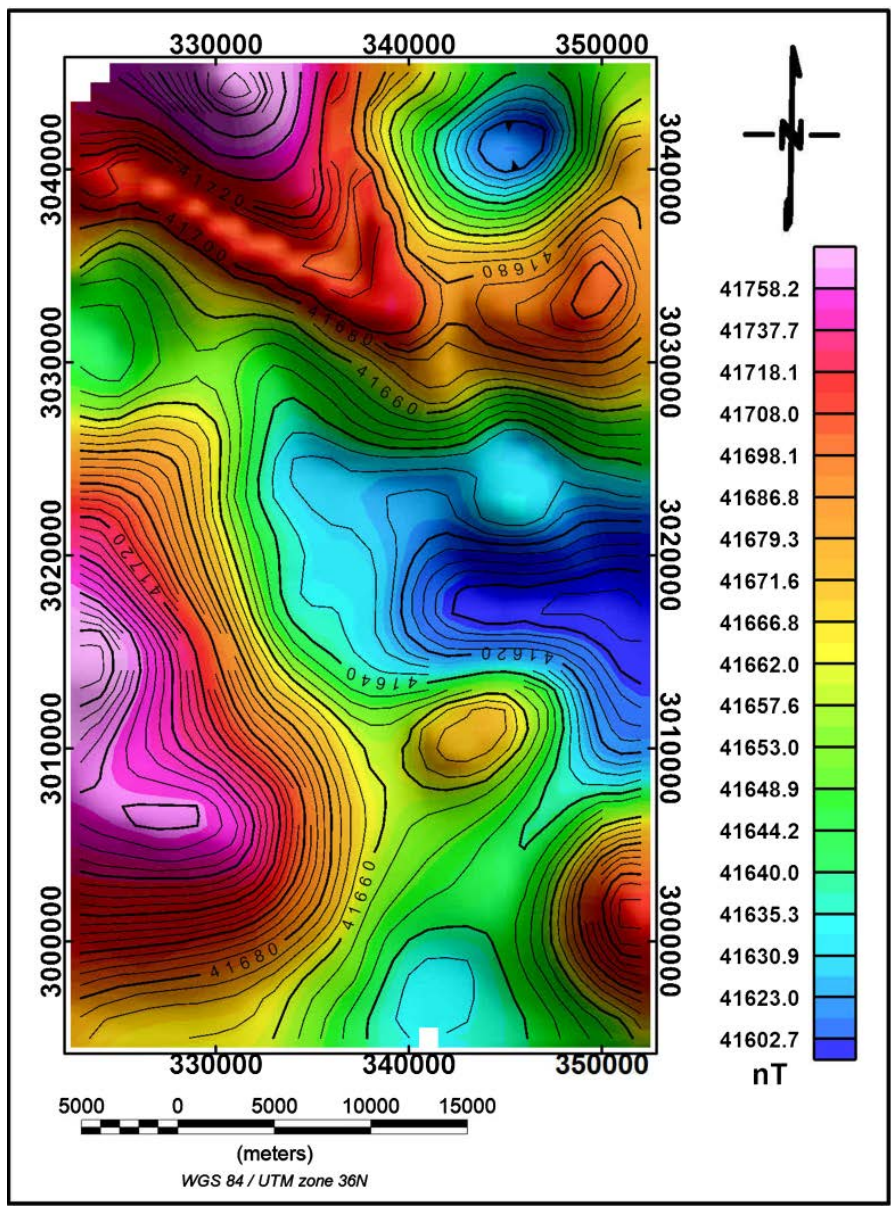

Figure 4. The TMI map of the study area.

analysis. It allows decision-makers to monitor changes in the area of interest without in situ field observations. The analysis of land cover and land use is an important remote sensing application in change detection studies. It is used to 
detect the changes that are happening in the cultivated lands by reclamation in the Wadi El Assiuti. Inspection of Figure 3 shows the land use in 2001 (A), 2011 (B), and 2019 (C). It has experienced dramatic changes since 2001. This is evidenced by the increase in the agricultural activities in the wadi, particularly at the entrance, close to the Nile River. The large increase in land reclamations, agricultural activities, and the heavy exploitation of the groundwater during recent years is making stress on the groundwater of the shallow aquifers. Therefore, a rapid decline in the water table is happening. However, the central and northeastern regions of the wadi show no development.

\subsection{The Aeromagnetic Data}

\subsubsection{Qualitative Interpretation}

Inspection of the reduced to the magnetic pole map (Figure 5) shows that the values of the measured magnetic intensity are varying from 41,574.8 to $41,852.1 \mathrm{nT}$ with the average of $41,664.7 \mathrm{nT}$. The variations in the magnetic intensity may be attributed to either lithology changes, basement topography, or faulting and folding. Low magnetic anomalies are located at the eastern parts of the study area, their values may indicate that there is a relatively deep magnetized source at those anomalies. Higher magnetic anomalies are shown at the

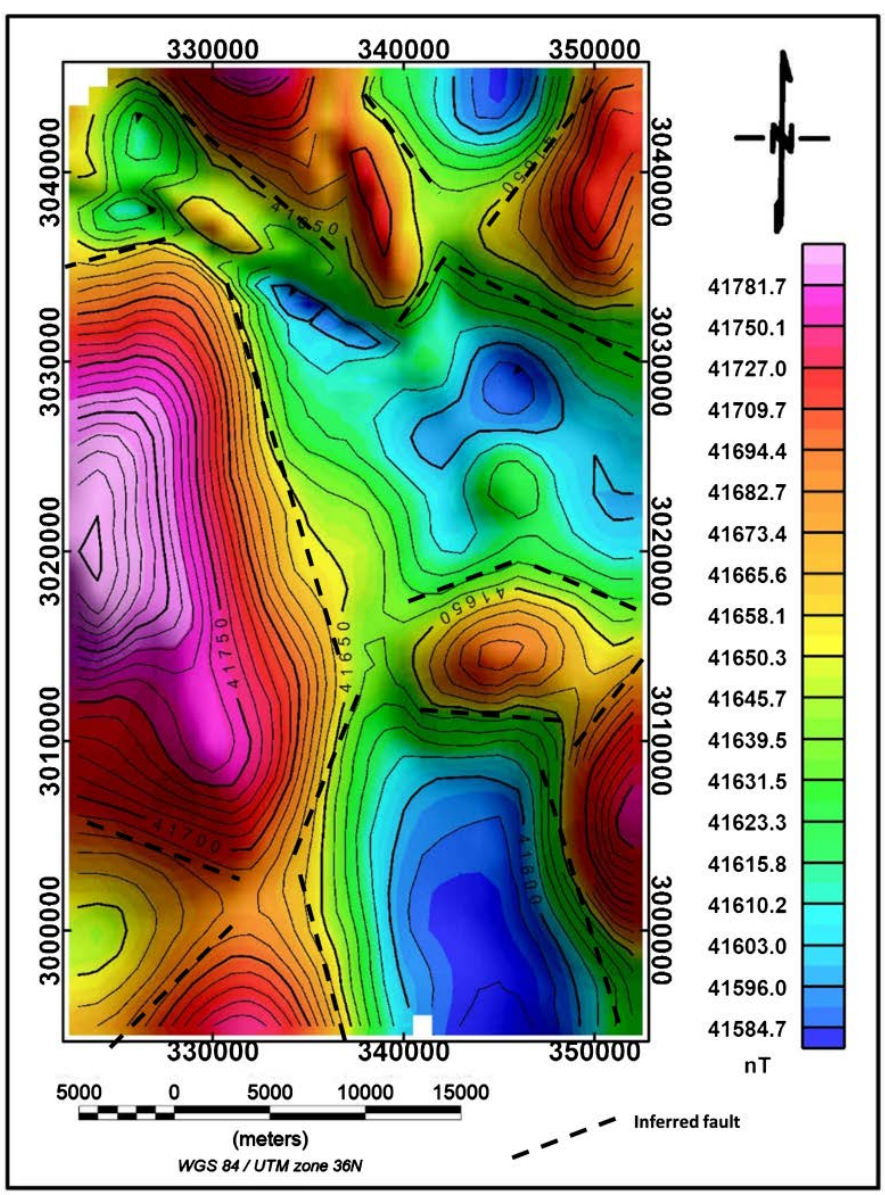

Figure 5. The RTP map of the study area and the inferred faults. 
western and northern parts of the area, reflecting the shallower depths of the magnetic sources.

\subsubsection{Quantitative Interpretation}

The magnetic anomaly data were quantitatively interpreted to delineate the structural trends affecting the area and to estimate the depth to the magnetic sources.

1) Delineation of the structural trends from the RTP magnetic anomaly map

Assiut region may be regarded as a good example that reflects the general structures of the stable paleogeographic and structural domain of the Arabo-Nubian shelf, bounded to the northwest by the mobile zone of the unstable shelf [14]. It was subjected to various tectonic events along the geologic time [9] [15] [16] [17] [18]. These tectonic events have resulted in changes in the structural setting of the area. These changes are appeared on the RTP magnetic map (Figure 5). The density and shape of the magnetic contour lines reflect these changes [19]. Therefore, the subsurface structural trends of the basement structures can be visually traced on the RTP map. Three structural trends are delineated in NW, NNW, and NE directions affecting the study area.

2) Delineation of the structural trends using the Total Horizontal Derivative (THDR) technique

The THDR technique was extensively used to detect the edges of the magnetized structures [20] [21]. It calculates the rate of change of the potential field in horizontal directions. The faulted boundaries might have high gradient areas and can be delineated from the horizontal derivative map.

Inspection of the THDR map (Figure 6) shows that the structural trends in the NW and NNW directions can be traced from it.

3) Delineation of the deeper structural trends using the continuation technique

Magnetic measurements are derived or observed at the Earth surface, at the airborne flight path, or at satellite altitude. In many instances, however, the magnetic information is not required at the measurement location. Thus, an upward or downward continuation process to a different height level has to be performed. Continuation filters are used to transform measured data into some new form; this is carried out by isolating, enhancing, and projecting the observed magnetic anomaly to other surfaces either above (upward continuation) or below (downward continuation) the original observation surface [22] [23].

The upward continuation maps of magnetic data $(Z=500,1000,2000,3000$, and $4000 \mathrm{~m}$; Figure 7) made it possible to highlight the great wavelength anomalies. The form and the extension of the anomalies are a function of the continuation distance. Inspection of Figure 7 in comparison to the RTP map (Figure 5) shows the adjacent anomaly sources produced increasingly overlapping anomalies as the height of the continuation level increasing and the effects of the shallow sources and noise are minimized. 


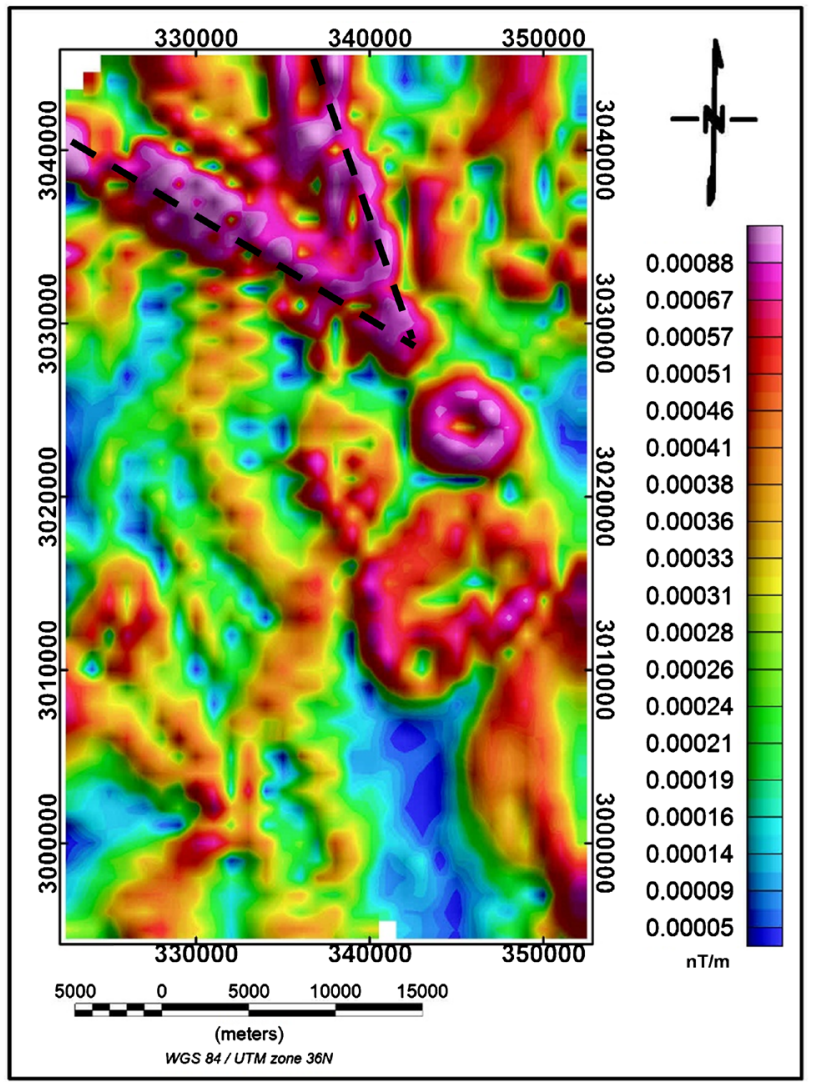

Figure 6. THDR magnetic map showing the faulting system of the magnetic structures.

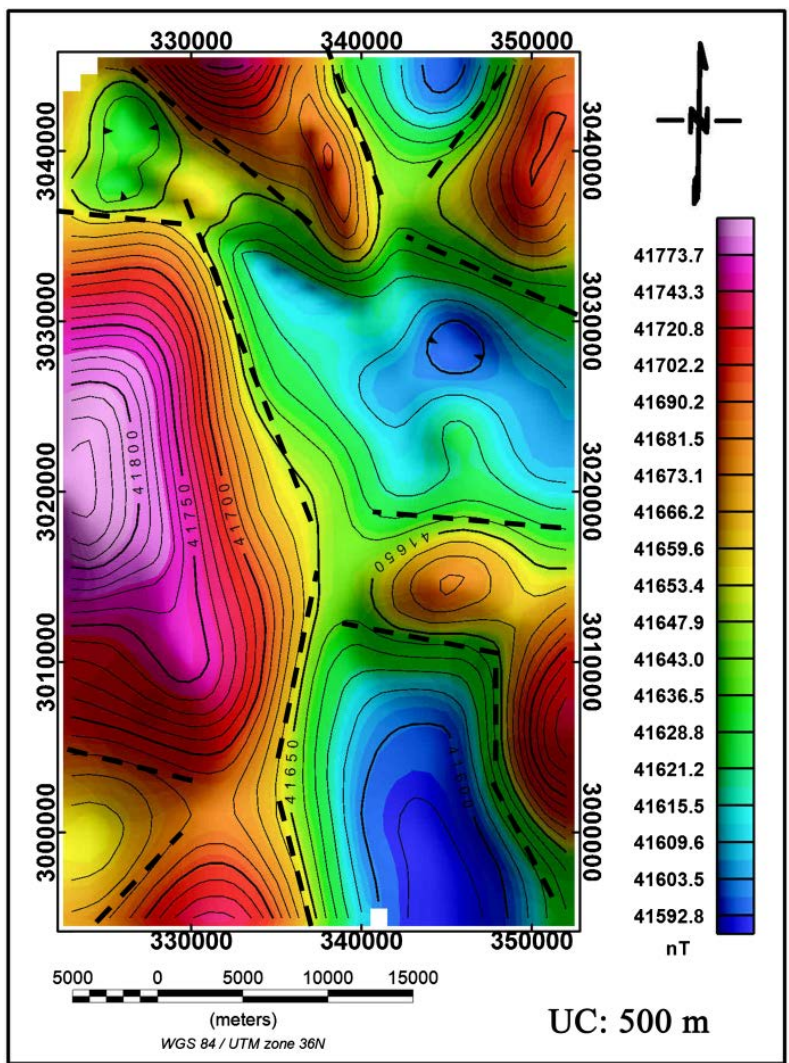



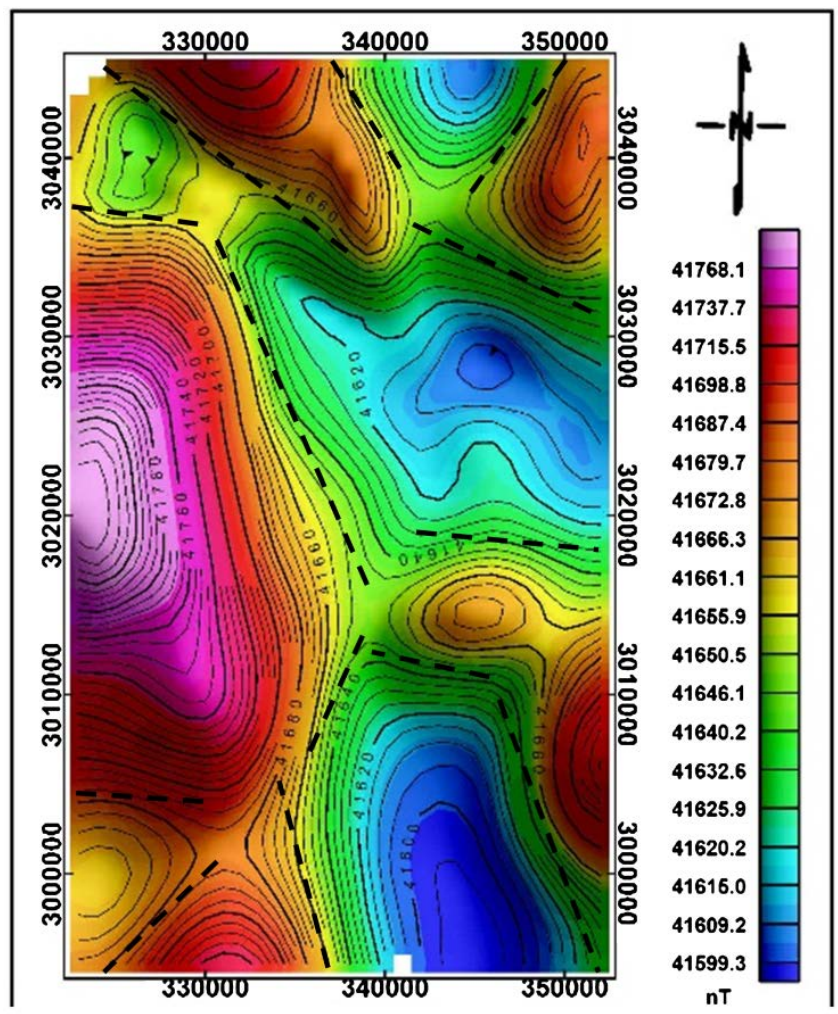

UC: $1000 \mathrm{~m}$

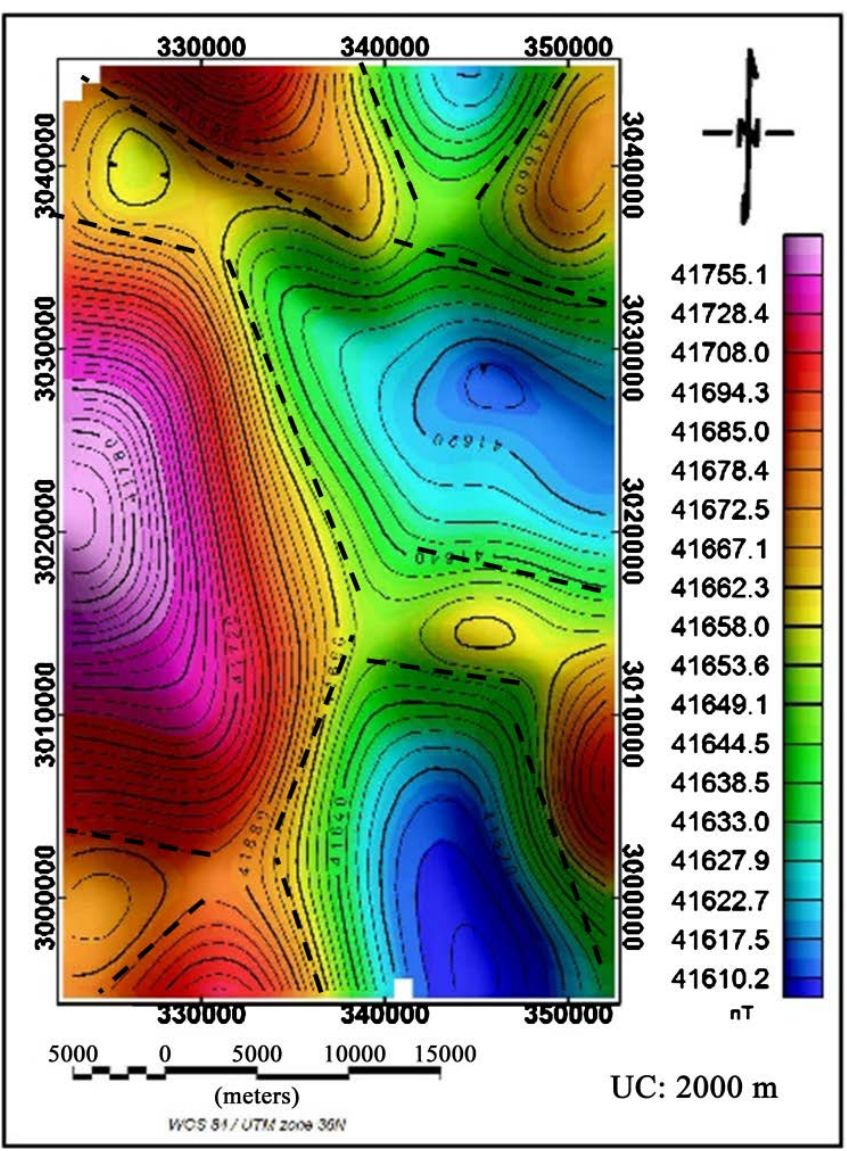




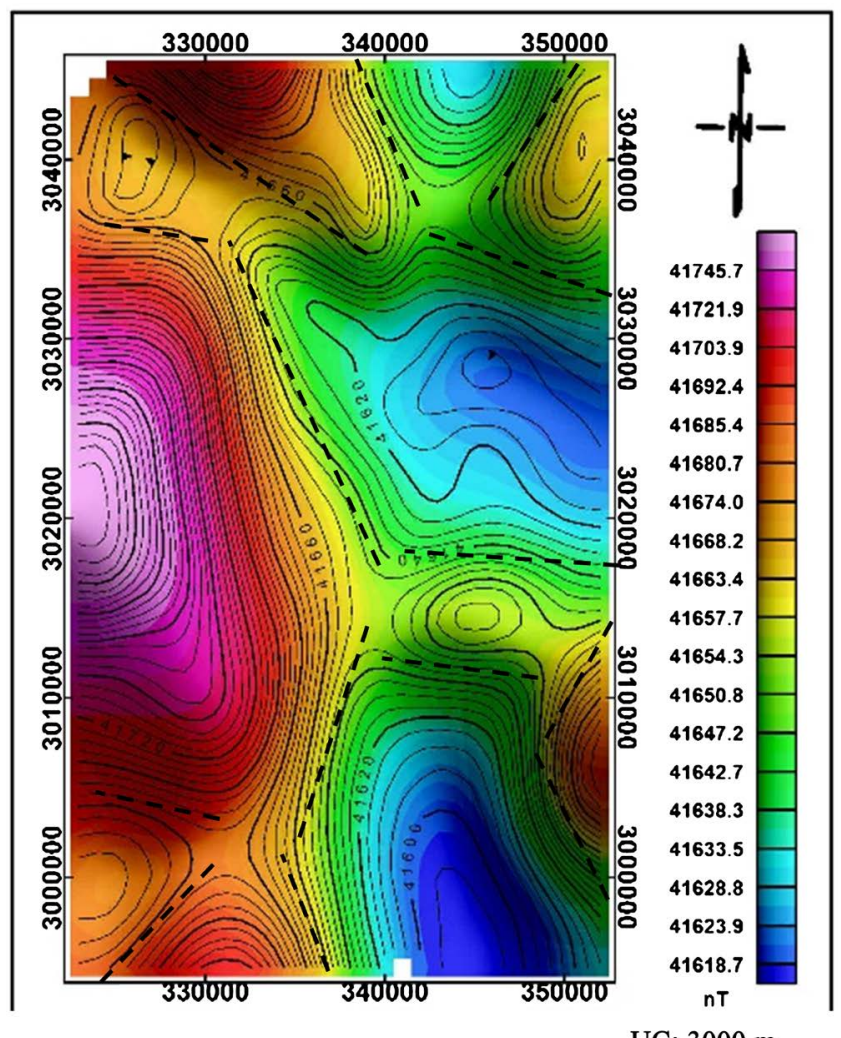

UC: $3000 \mathrm{~m}$

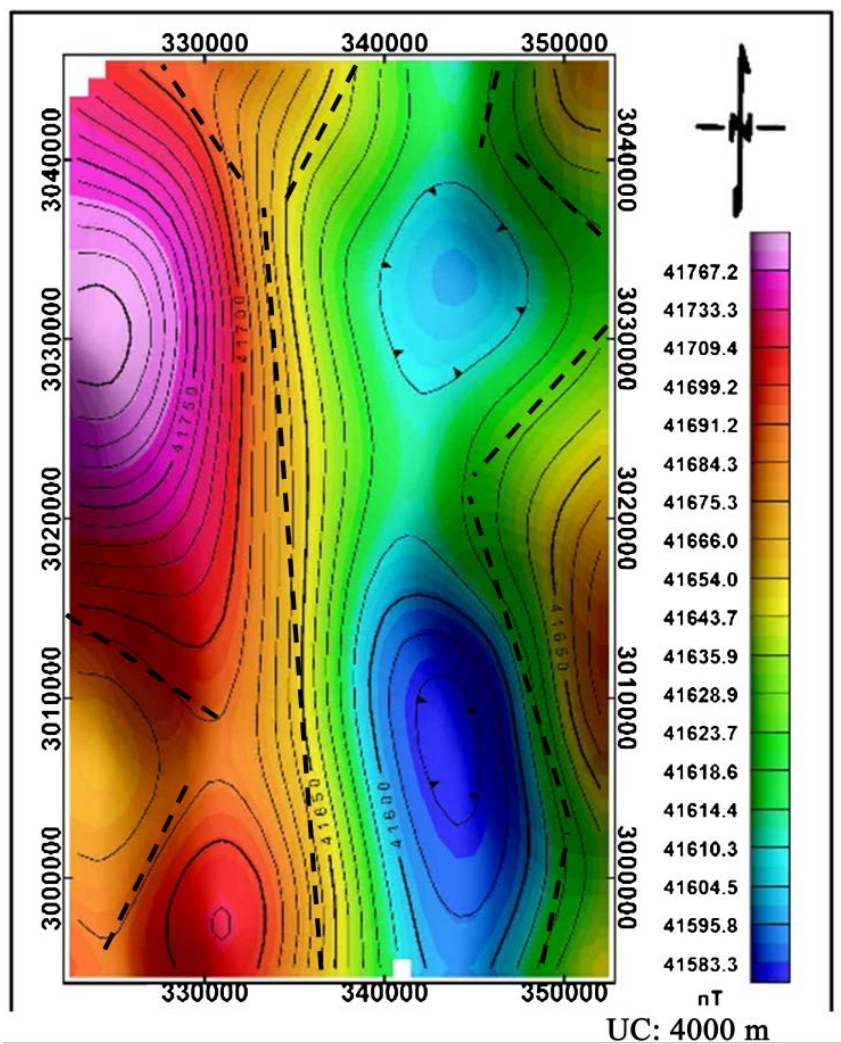

Figure 7. Upward continued magnetic maps (Upward continuation: $500-4000 \mathrm{~m}$ ) and the inferred faults. 
The regional magnetic anomaly maps (Figure 7) indicate that the anomalies observed on the RTP map (Figure 5) are the manifestations of the deeper magnetic anomalies. Inspection of these maps suggests deep-seated faults alignment in the NNW, NW, NE, E-W directions at the deeper part.

4) Delineation of the structural trends using the Tilt Derivative (TDR) technique

The TDR technique was used to sharpen the potential field anomalies. It was defined by [24]. The tilt angle is positive when over the source, near the edge as the vertical derivative is zero and the horizontal derivative is maximum and is negative outside the source region. From the zero value of the TDR, the outline of the edges can be identified [24]. The tilt amplitudes have values ranging between $-\pi / 2$ to $+\pi / 2$. Its zero contour line is located over or close to the edges of the faults. Inspection of the TDR of the RTP and the upward-continuation maps (Figure 8) and the zero contour line shows the magnetic anomalies are almost aligned in definite directions forming structural trends in NNW, NW, and NE directions.

\subsubsection{Depth to the Basement Rocks}

The $2 \mathrm{D}$ modeling of the magnetic data was conducted to investigate the subsurface geology and to calculate the depth to the basement rocks. The $2 \mathrm{D}$ modeling of the magnetic data was performed based on the techniques, given by [25] [26]. The 2D models were generated along east-west profiles (Figure 9) on the reduced to pole magnetic map using GM-SYS Geosoft [13]. The GM-SYS inversion option

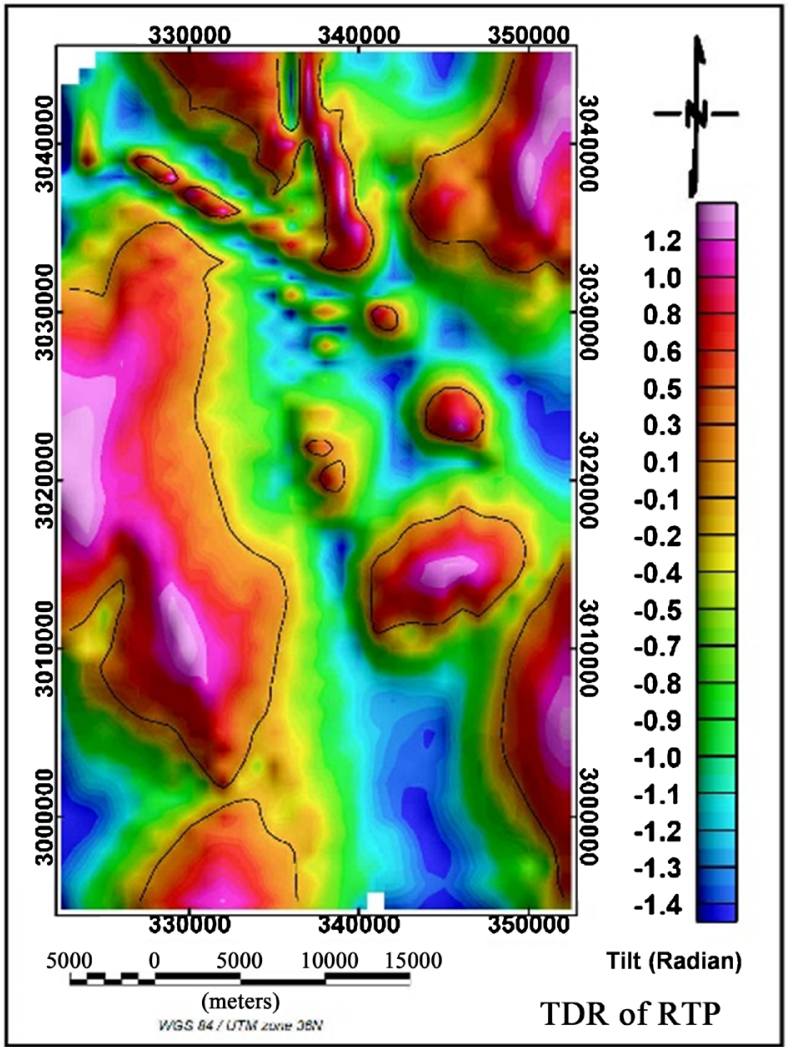



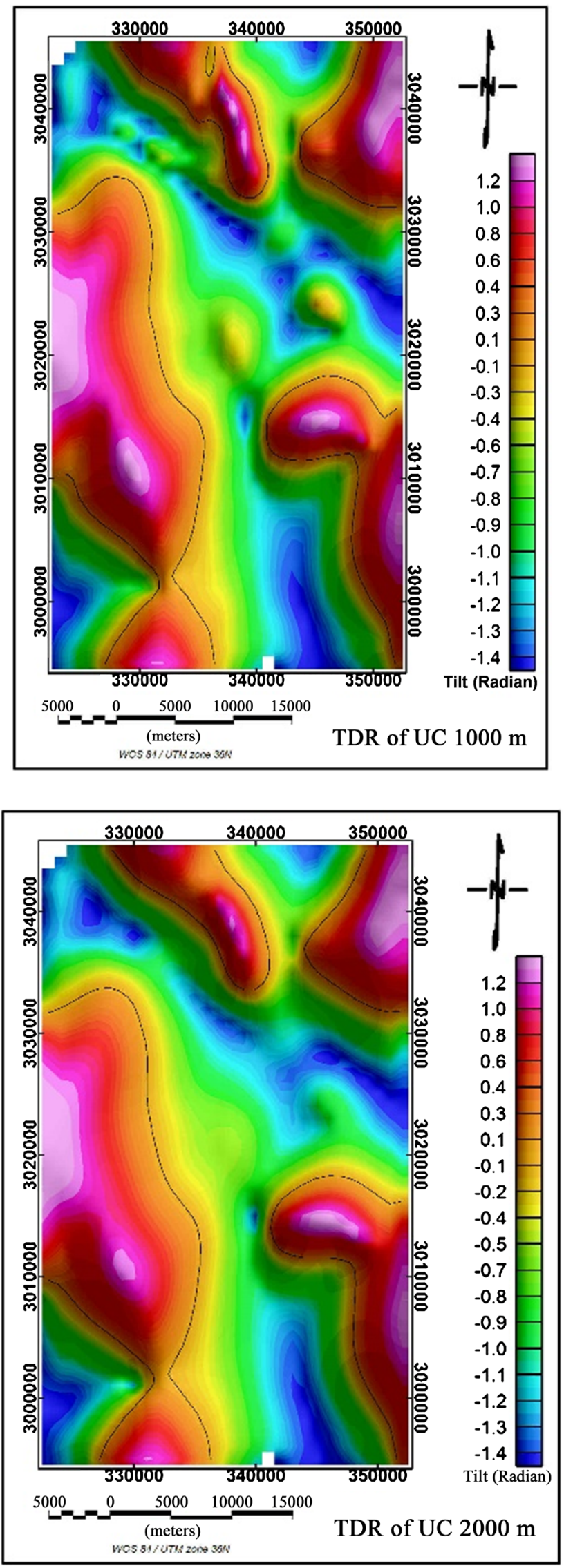

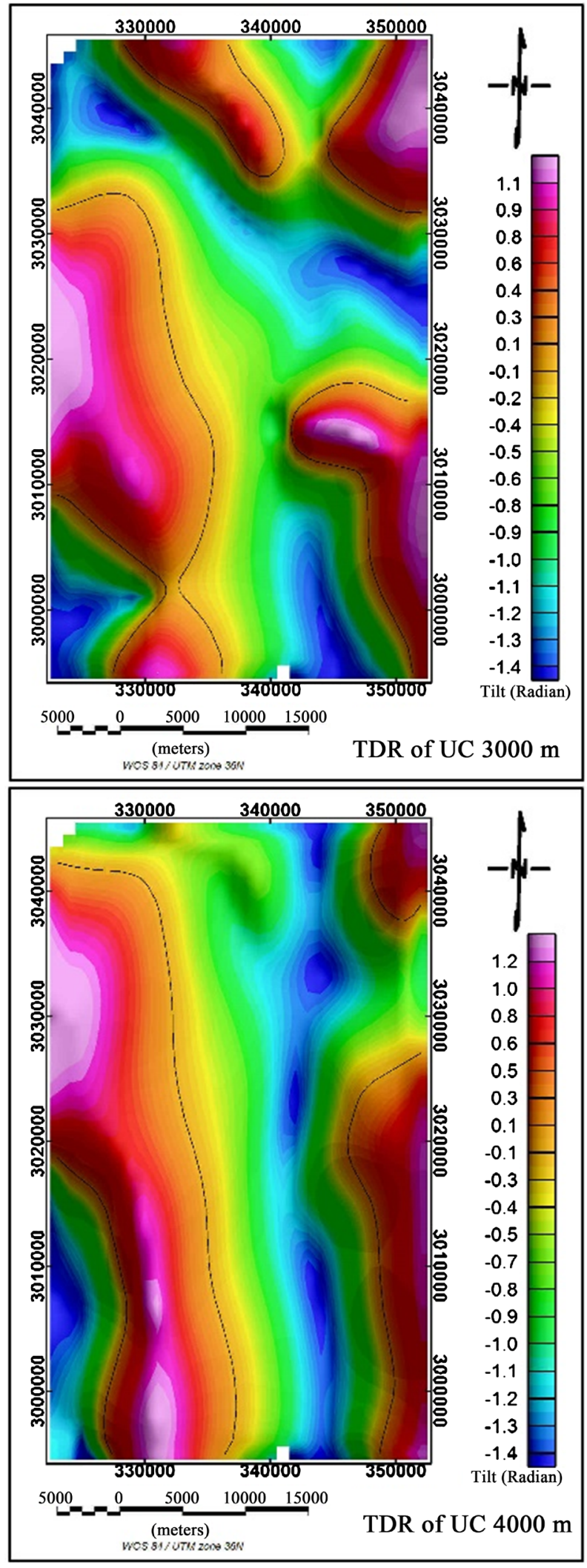

Figure 8. Tilt derivative angle (TDR) maps (the boundary of the anomaly source is given as a black line) of the RTP and the upward-continued magnetic maps (Upward continuation: $1000-4000 \mathrm{~m}$ ). 


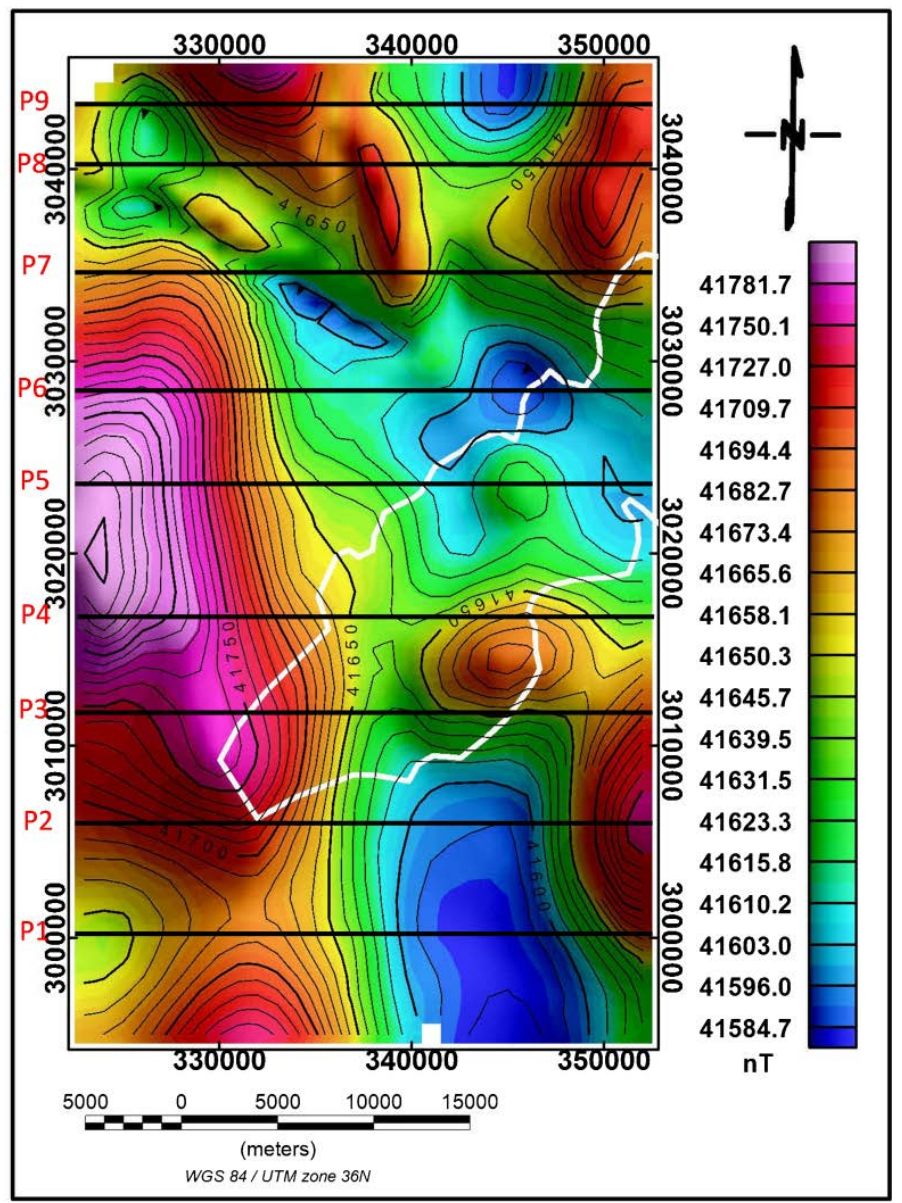

Figure 9. Locations of the 2D magnetic profiles on the RTP map.

allows us to optimize the model. Several earth models can produce the same magnetic and/or gravity response. The interpreter can evaluate the geologic reasonableness of any model [27]. These 2D models assume the earth is two dimensional and changes are in $\mathrm{Z}$ and $\mathrm{X}$ directions of the profile. The magnetic susceptibility values of $0.00050-0.00085$ CGS units were adopted from the work of [28] [29]. The final models of the profiles are shown in Figure 10. Inspection of these models shows that the depth to the basement rocks is generally increasing southeastward from $\sim 2.24 \mathrm{~km}$ at the western parts of the plateau to $\sim 4.84 \mathrm{~km}$ at the southeastern parts of the study area, close to the Nile Valley.

\section{Analysis of Structural Trends}

The analysis of the magnetic data shows that the positive anomalies indicate higher relief of crystalline rocks, while the negative anomalies indicate lower relief or down-thrown blocks of crystalline rocks. No subsurface igneous activity was observed from the analysis of the data. Moreover, the negative anomaly values indicate the presence of deep sedimentary basins. A group of NNW, NW, $\mathrm{NE}$, and E-W striking deep-seated faults is delineated from the reduced to pole map, total horizontal and tilt derivatives, and the upward continuation maps. 

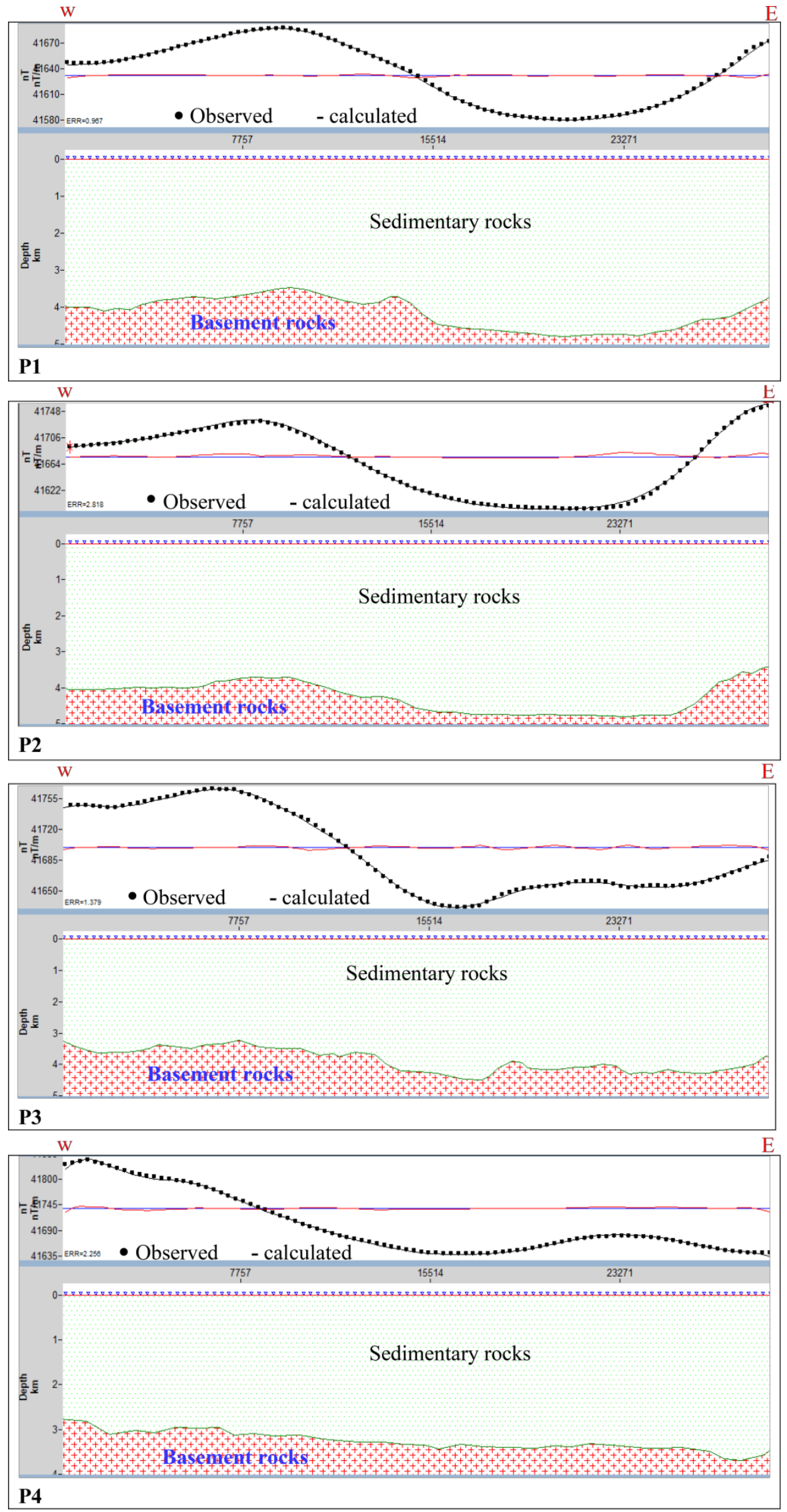

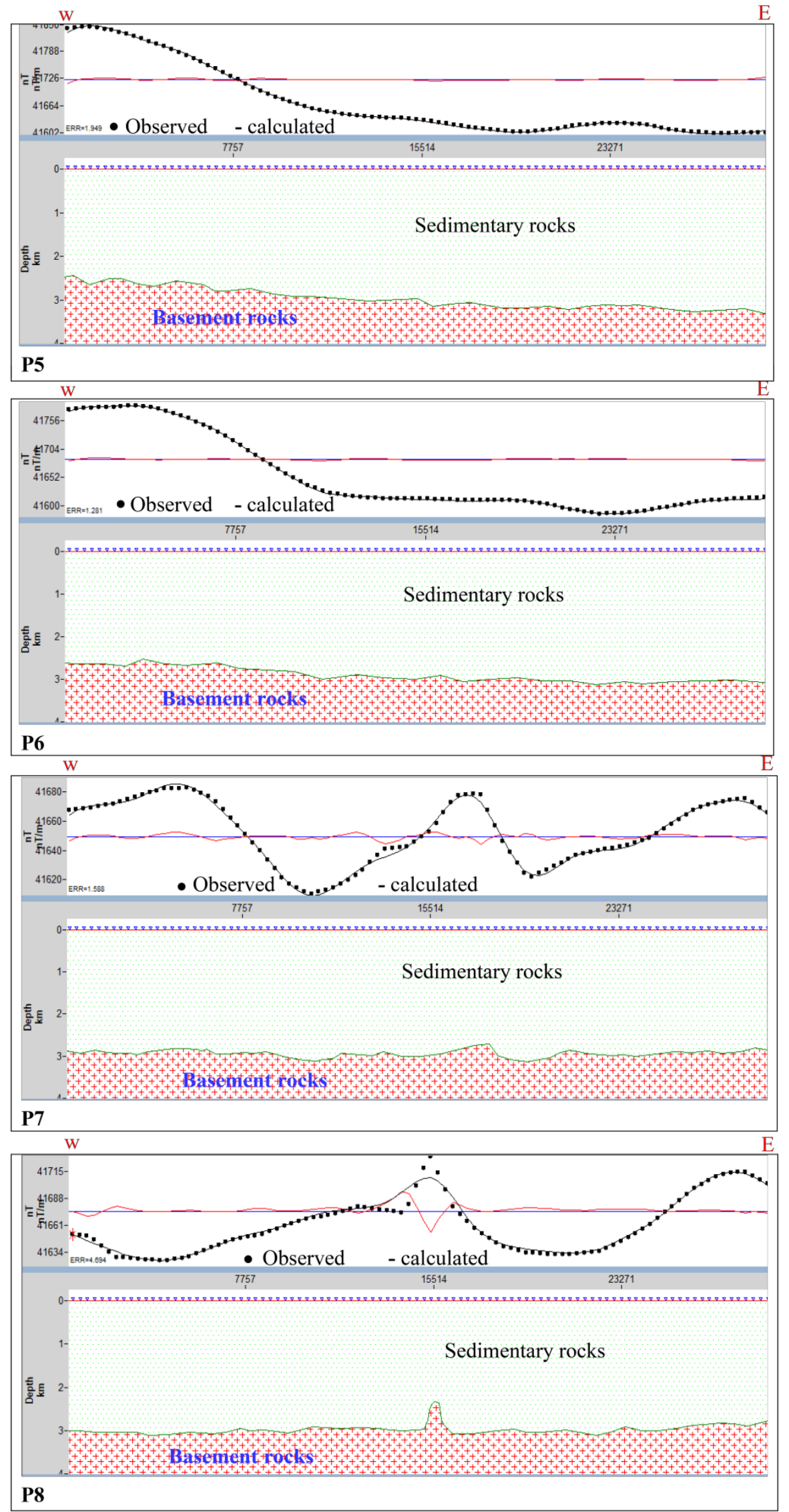


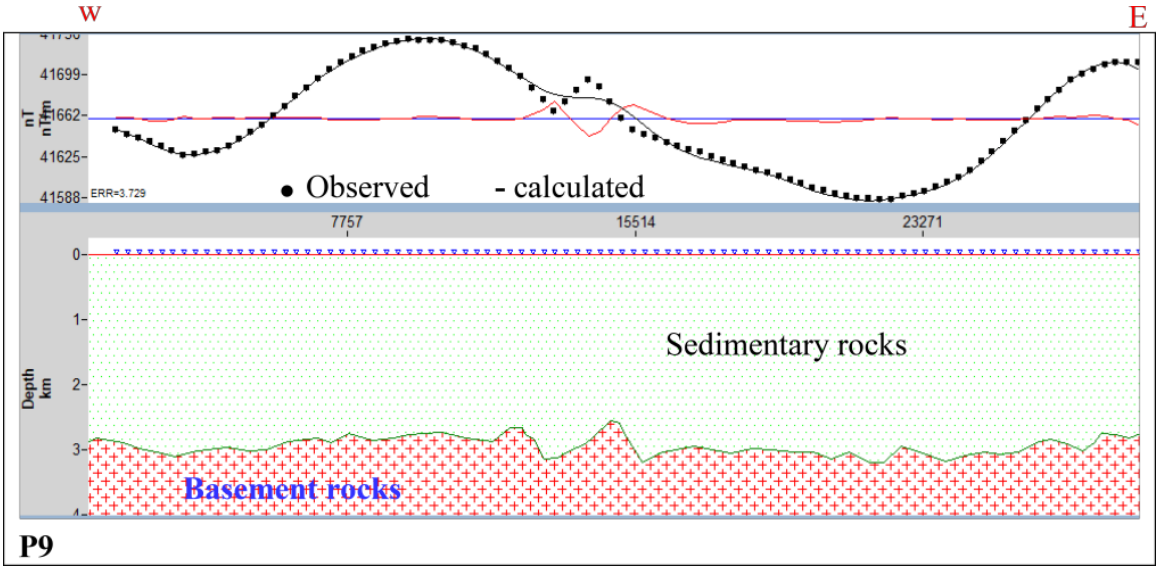

Figure 10. The 2D magnetic models for profiles P1 - P9.

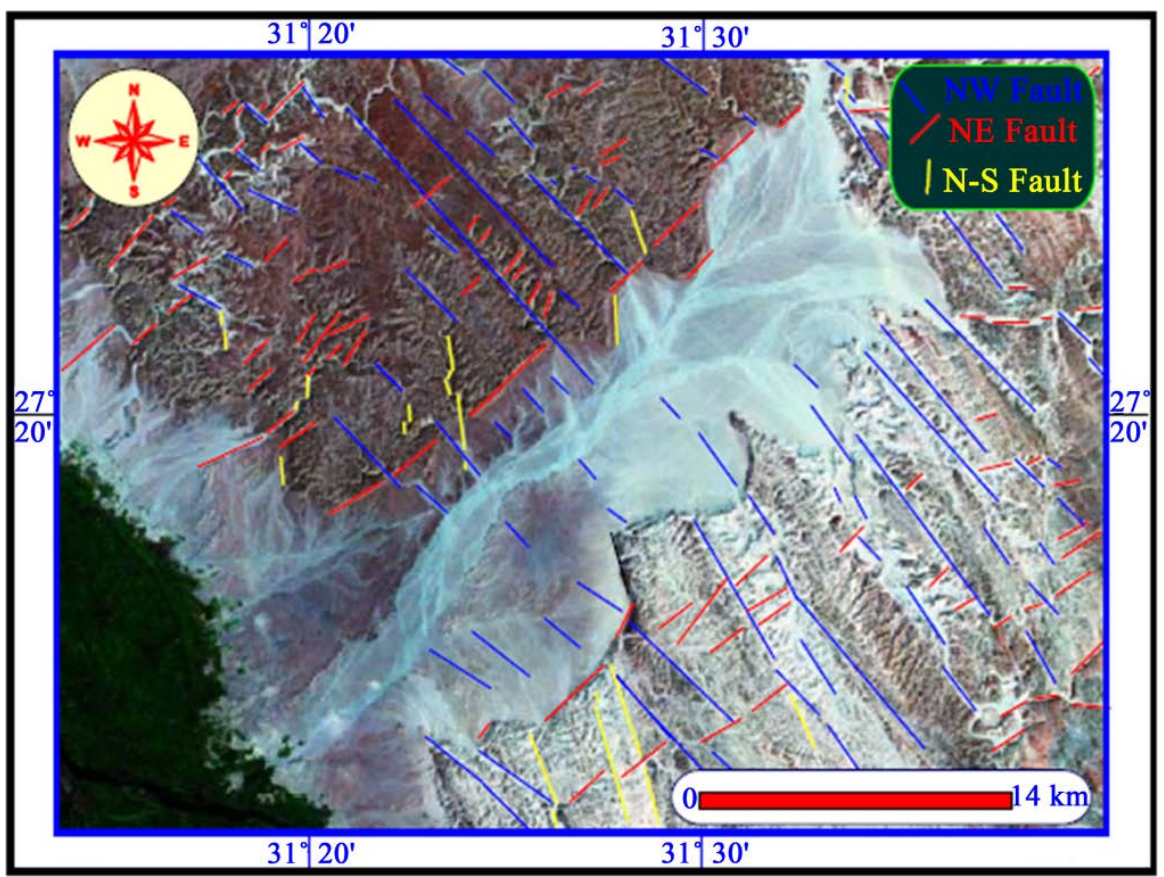

Figure 11. Main fault systems of Wadi El Assiuti [9].

These faults are responsible for the formation of basinal areas. [9] has delineated three main surface fault systems in Wadi El Assiuti using thematic mapper satellite data. The three trends are arranged in decreasing order as NW (Clysmic), NE, E-W (Tethyian), and N-S (Figure 11), with the active NW fault system. This is obvious from the higher extension and continuity of the NW fault trend[9] . These major surface features are a reflection of the basement structures [16]. The deep-seated sub-vertical NW-trending Neoproterozoic faults have been reactivated during the Neogene rifting events resulted from the Red Sea opening. These faults are part of the Najd Shear System [30], the largest pre-Mesozoic faulting system on the Earth [31], alignment in an NW-SW direction (Figure 12). The system extends into the Eastern Desert [31] [32]. The integration of the surface major fault features with the structural trends delineated from the magnetic 


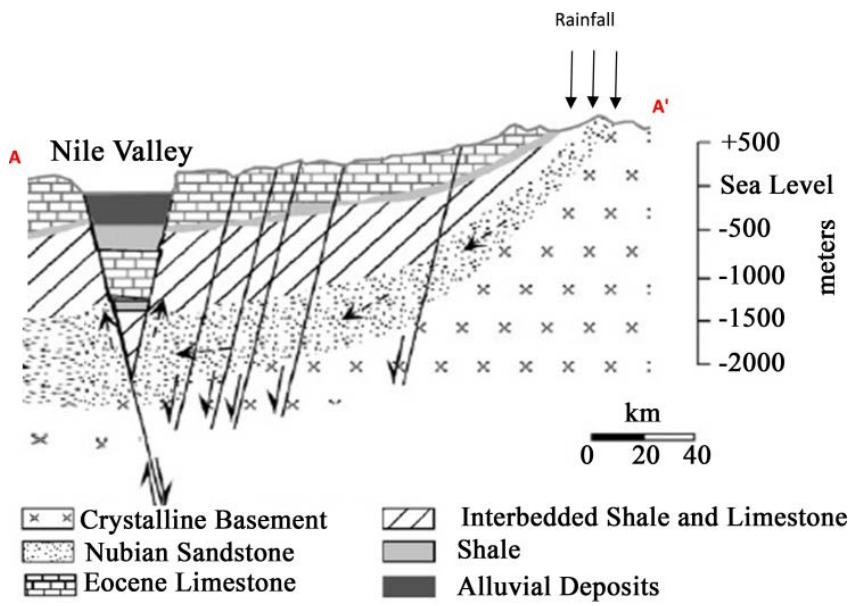

Figure 12. A geological cross-section (AA', Figure 1) extending from west Assiut area (west) to Red Sea Hills (east) [44].

data indicates the continuity of the faults within the sedimentary succession and the basement rocks. This leads to a hydraulic connection between the deep and shallow aquifers.

\section{Groundwater Aquifers}

Two shallow aquifers represent the groundwater resources in the wadi. The shallow Quaternary aquifer is the recent water-bearing source in the Nile valley and the main wadis in Egypt. It is represented by Quaternary alluvial deposits, which are considered as a promising aquifer [10]. It is consisted of course to medium sands with a thickness of about $55 \mathrm{~m}$ in the eastern part, and coarse to fine sands with a thickness of $\sim 75 \mathrm{~m}$ in the western part. The Quaternary aquifer is considered as a semi-confined aquifer in the eastern part and a confined in the western part. The lower Plio-Pleistocene aquifer underlines the Quaternary sediments and overlies the Pliocene clays in Wadi El Assiuti area. It is composed of successions of sandy layers and/or lenses separated by clayey layers [33]. This aquifer is represented by two water-bearing zones, the upper one with $\sim 40 \mathrm{~m}$ thick, while the lower zone has more thickness. Sandy clays are intercalated between these two zones. Two deep aquifers (Nubian Sandstone and Fractured Limestone aquifers; Figure 12 \& Figure 13) generally represent the main groundwater resources in the Eastern and Western deserts.

The Fractured Limestone aquifer overlies the Nubian Sandstone aquifer and underlies the Quaternary aquifer. The fissured carbonate rocks are represented by a three-horizon system: Upper Cretaceous, Paleogene, and Neogene horizons, separated by other facies layers. Based on a three-horizon concept, it is possible to study the surface and subsurface occurrences, the depth and thickness of each horizon, and the presence and quality of groundwater.

These large groundwater aquifers show good behaviors in response to natural and/or anthropogenic activities. The Earth's gravity field anomalies from the Gravity Recovery and Climate Experiment satellite mission have been widely 


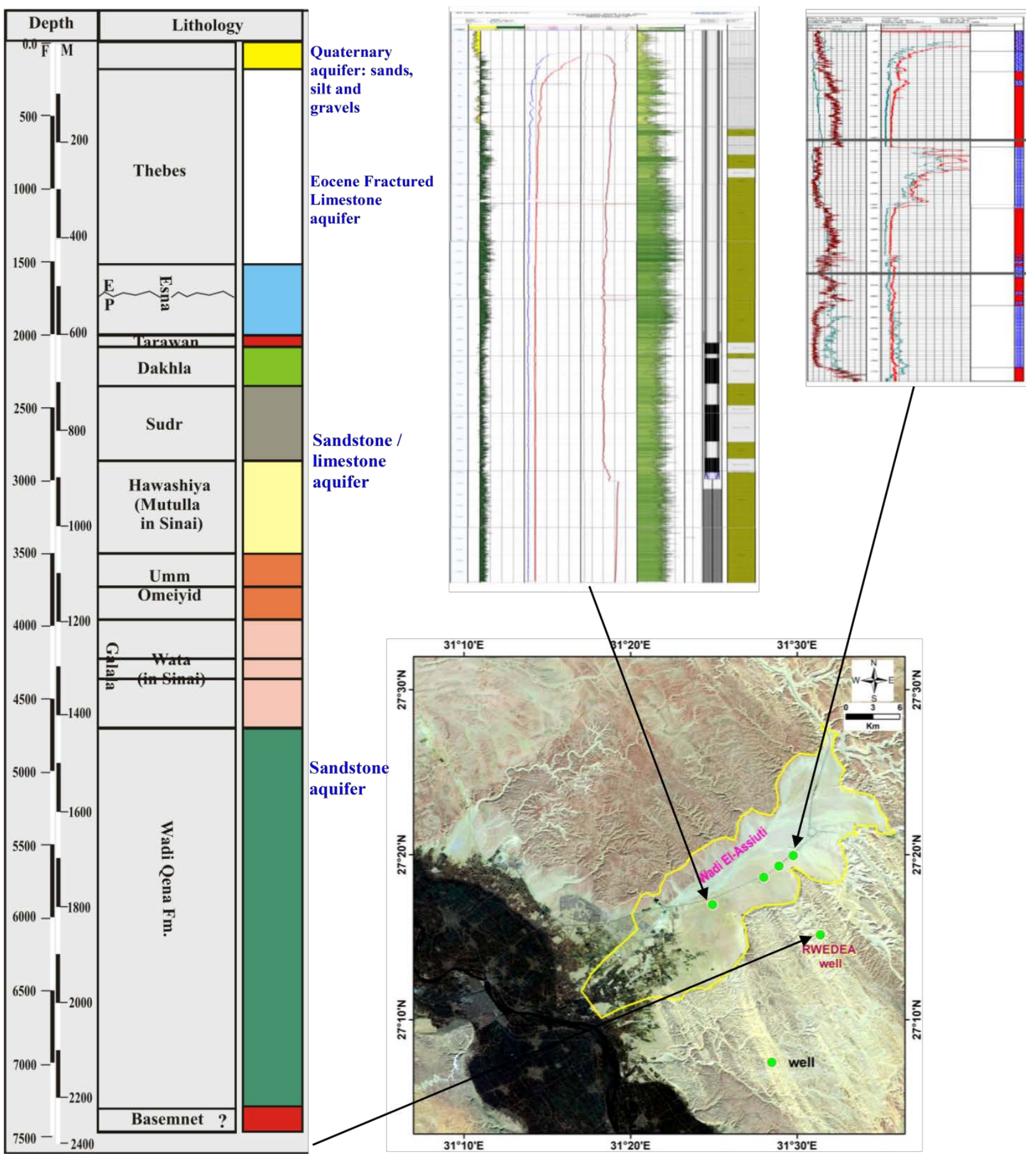

Figure 13. Borehole data used in the current study. The RWEDEA well was drilled by Apache Petroleum Company.

applied for monitoring the groundwater storage variations and estimating the aquifer depletion and/or recharge worldwide [34]-[41].

\section{Suitable Sites for Well Drilling}

Based on the integration of the results and interpretations of the magnetic data with the borehole data of the available wells, the first zone of groundwater re- 
sources is represented by the Quaternary aquifer that is consisted of sands, silt, and gravels. The second zone is represented by about $400 \mathrm{~m}$ thick of Eocene carbonate rocks forming the Fractured Limestone aquifer. The transitional zone is represented by the Upper Cretaceous Sandstone/Limestone aquifer (Figure 13). It is a transitional aquifer between the overlying Fractured Limestone aquifer and the underlying Nubian Sandstone aquifer (NSA). The NSA extends over $2 \times 10^{6} \mathrm{~km}^{2}$ in NE Africa. It is represented mainly by water-bearing Paleozoic-Mesozoic Nubian Sandstone with Tertiary marine shale and clay intercalations [42]. The NSA represents the most important deeper aquifers, provided that the higher thickness of the sandstone in the sedimentary basin of the study area of good hydrological properties.

The depth and thickness of the NSA in the Eastern desert show a progressive increase from the Red Sea Hills toward the Nile River based on geophysical and borehole information (Figure 12 \& Figure 13). Surface and subsurface water are feeding the Nubian sandstone outcrops, close to the Red Sea Hills, and flowing toward the Nile Valley following the gentle slope of the layers. As a consequence, the groundwater level is lower in the study area in comparison to the source areas at the Red Sea Hills. From another side, the NSA is confined north of latitude $25^{\circ} \mathrm{N}$ in Egypt. The confining layer is composed of marine shale [42]. All these conditions help the sub-vertical faults act as conduits for ascending

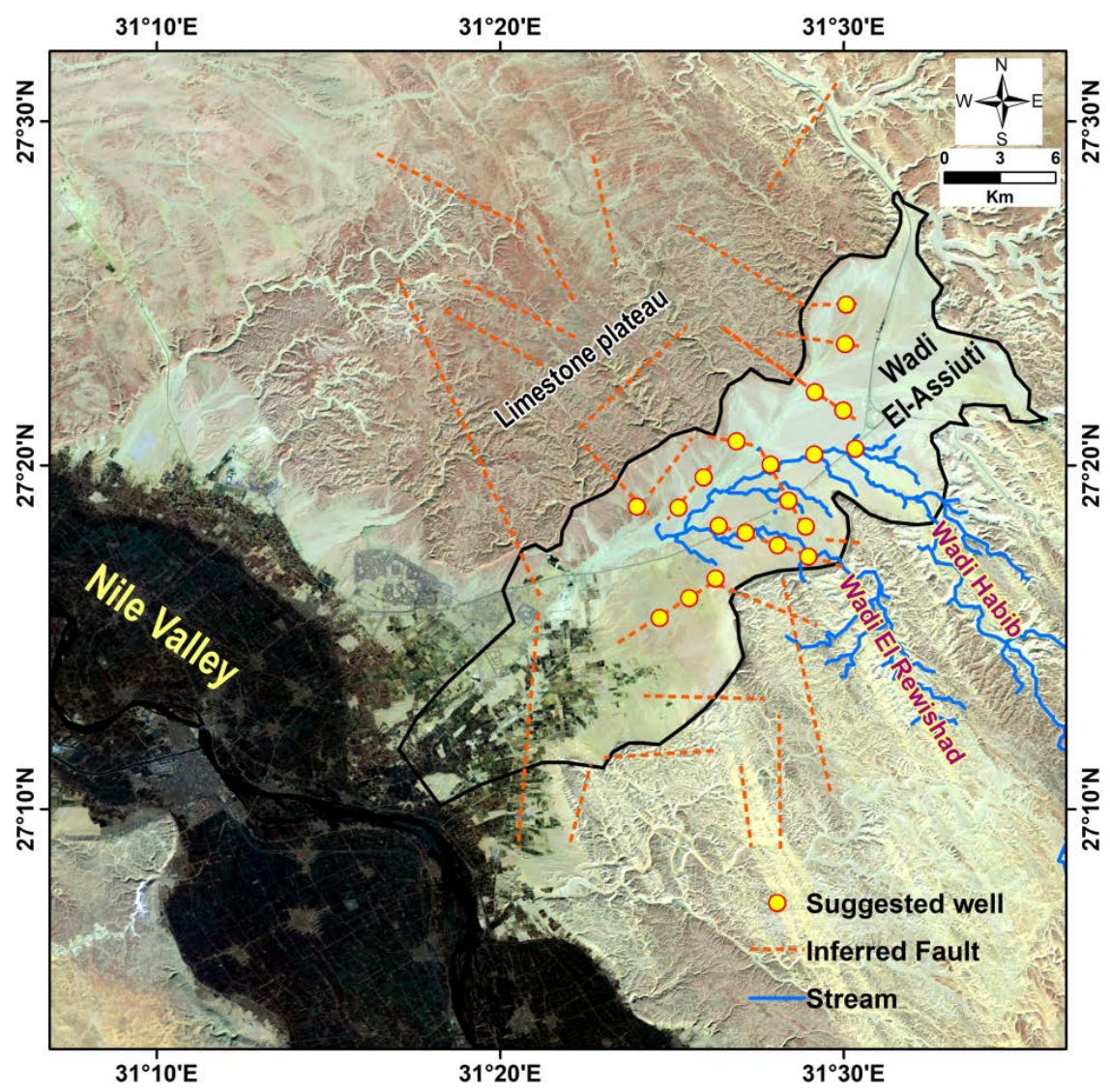

Figure 14. Showing the suggested locations for water well drilling in the study area. 
groundwater from the deeper NSA [2] [43] into the Quaternary aquifer proximal to Nile River (Figure 12). This is evidenced by the depleted isotopic compositions of groundwater samples, collected from the entrance of the wadi (Figure 1) [2]. This indicates that these paleowaters are ascending from the Nubian Aquifer along the deep-seated faults at depths exceeding $1 \mathrm{~km}$. As a result of the upward leakage along the sub-vertical faults, drilling shallow wells within the zones of these faults can get water from the deeper aquifer and minimize the cost of deep drilling. Thus, based on the integration of the sedimentary thickness and the locations of the faults from the magnetic data, the best sites (Figure 14) could be identified for drilling newly deep wells tapping the deeper NSA in the deep sedimentary basin and/or shallow wells, close to the deep-seated faults. Zones of these faults, enhance porosity, and facilitate the upward flow of the groundwater.

\section{Conclusion}

The magnetic data were used to delineate the structural trends affecting the groundwater resource of Wadi El Assiuti, and to calculate the depth of the basement rocks. The thickness of the sediments is increasing from $\sim 2.24 \mathrm{~km}$ at the western parts of the plateau to $\sim 4.84 \mathrm{~km}$ toward the eastern parts of the wa$\mathrm{di}$, where the wadi forming deep sedimentary basins. Several structural trends are delineated in the NNW, NW, NE, and E-W directions affecting the area, with no igneous activity. These deep-seated faults are the most active trends cutting the basement and sedimentary cover, which is providing conduits for groundwater flow from the deeper aquifers into the shallow aquifers. The deltas of Wadi El Rewishad and Wadi Habib represent the most promising areas for drilling new wells in the uncultivated area, given the higher thickness of the sediments and the occurrence of the deep-seated NW, NE and E-W trending sub-vertical faults.

\section{Acknowledgements}

Funding was provided by Science \& Technology Development Fund (Project ID: 25274) awarded to Assiut University. We thank the editor and reviewers of the $I J G$ for their instructive comments and suggestions.

\section{Conflicts of Interest}

The authors declare no conflicts of interest regarding the publication of this paper.

\section{References}

[1] Elewa, H.H. (2008) Prediction of Future Drawdown of Water Levels of the Pleistocene Aquifer System of Wadi El-Assiuty Area, Eastern Desert, Egypt, as a Criterion for Management and Conservation. Resources, Conservation and Recycling, 52 1006-1014. https://doi.org/10.1016/i.resconrec.2008.03.006

[2] Sultan, M., Yan, E., Sturchio, N., Wagdy, A., Abdel Gelil, K., Becker, R., Manocha, N. and Milewski, A. (2007) Natural Discharge: A Key to Sustainable Utilization of 
Fossil Groundwater. Journal of Hydrology, 335, 25-36. https://doi.org/10.1016/j.jhydrol.2006.10.034

[3] Al-Garni, M.A., Hassanein, H.I. and Gobashy, M. (2005) Ground-Magnetic Survey and Schlumberger Sounding for Identifying the Subsurface Geologic Factors Controlling the Ground Water Flow along Wadi Lusab, Makkah Al-Mukarramah, KSA. Journal of Applied Geophysics, 4, 59-74.

[4] Al-Garni, M.A., Hassanein, H. and Gobashy, M. (2006) Geophysical Investigation of Groundwater in Wadi Lusab, Haddat Ash Sham Area, Makkah Al-Mukarramah, Arab Gulf. Journal of Scientific Research, 24, 83-93.

[5] Araffa, S.A.S., Sabet, H.S. and Abed, M.A. (2020) Application of Magnetic and Resistivity for Groundwater Investigations at North Al Ain Sokhona-Cairo Road, Al Ain Sokhna, Egypt. NRIAG Journal of Astronomy and Geophysics, 9, 280-288. https://doi.org/10.1080/20909977.2020.1746894

[6] Said, R. (1981) The Geological Evolution of the River Nile. Springer Verlag, New York, 151. https://doi.org/10.1007/978-1-4612-5841-4

[7] Said, R. (1990) The Geology of Egypt. Elsevier, New York, 734.

[8] Bakheit, A.A., Senosy, M.A., Riad, S., Omran, A.A. and Ibrahim, H.A. (1993) Application of the Resistivity Method to Study Ground Water Potentialities on a Part of the Entrance of Wadi El-Assiuti, Eastern Desert, Egypt. Qatar University Science Journal, 13, 341-347.

[9] Yousef, A.F. (2008) The Impact of North West Active Fault System on the Recharge of the Quaternary Aquifer System around the Nile Valley: Case Study Wadi El-Assiuty, Eastern Desert. Egypt. European Water, 21/22, 41-55.

[10] Dawoud, M.A. and Ewea, H.A. (2011) Sustainable Development via Optimal Integration of Surface and Groundwater in Arid Environment: Nile River Quaternary Aquifer Case Study. Journal of King Abdulaziz University-Meteorology Environment and Arid Land Agriculture Sciences, 22, 19-45.

https://doi.org/10.4197/Met.22-3.2

[11] Farrag A.A., Ebraheem, M.O., Sawires, R., Ibrahim, H.A. and Khalil, A.L. (2018) Petrophysical and Aquifer Parameters Estimation Using Geophysical Well Logging and Hydrogeological Data, Wadi El-Assiuoti, Eastern Desert, Egypt. Journal of African Earth Sciences, 149, 42-54. https://doi.org/10.1016/j.jafrearsci.2018.07.023

[12] Mohamed, A., Ragaa Eldeen, E. and Abdelmalik, K. (2021) Gravity Based Assessment of Spatio-Temporal Mass Variations of the Groundwater Resources in the Eastern Desert, Egypt (Submitted). Arabian Journal of Geosciences.

[13] Geosoft Oasis Montaj (2015) Data Processing and Analysis Systems for Earth Science Applications (Ver. 8.3.3). Geosoft Inc., Toronto.

[14] Said, R. (1962) The Geology of Egypt. Elsevier, Amesterdam, New York, 377.

[15] Yallouze, M. and Kentsch, G. (1954) Linear Structures in and around the Nile Basin (Comparative Analysis of Tectonic Evolution in North Africa). Bulletin of the Egyptian Geographical Society, 27, 154-207.

[16] Youssef, M.I. (1968) Structural Pattern of Egypt and Its Interpretation. AAPG Bulletin, 52, 601-614.

https://doi.org/10.1306/5D25C44D-16C1-11D7-8645000102C1865D

[17] Youssef, M.M., Riad, S. and Mansour, H.H. (1977) Surface and Subsurface Structural Study of the Area around Assiut, Egypt. Bulletin of the Faculty of Science, Assiut University, 6, 293-306.

[18] Rizkalla, I.R. (1989) Interpretation of Aero-Magnetic Data around Assiut Area, 
Eastern Desert, Egypt. Egyptian Geological Society Proceeding of the 7 th Annual Meeting, Cairo, March 1989, 65-76.

[19] Al-Garni, M.A. (2010) Magnetic Survey for Delineating Subsurface Structures and Estimating Magnetic Sources Depth, Wadi Fatima, KSA. Journal of King Saud University (Science), 22, 87-96. https://doi.org/10.1016/j.jksus.2010.02.005

[20] Cooper, G.R.J. and Cowan, D.R. (2006) Enhancing Potential Field Data Using Filters Based on the Local Phase. Computers \& Geosciences, 32, 1585-1591. https://doi.org/10.1016/j.cageo.2006.02.016

[21] Cooper, G.R. (2009) Balancing Images of Potential-Field Data. Geophysics, 74, L17-L20. https://doi.org/10.1190/1.3096615

[22] Pawlowski, R.S. (1995) Preferential Continuation for Potential-Field Anomaly Enhancement. Geophysics, 60, 390-398. https://doi.org/10.1190/1.1443775

[23] Blakely, R.J. (1996) Potential Theory in Gravity and Magnetic. Cambridge University Press, New York, 441. https://doi.org/10.1017/CBO9780511549816

[24] Miller, H.G. and Singh, V. (1994) Potential Field Tilt-A New Concept for Location of Potential Field Sources. Journal of Applied Geophysics, 32, 213-217. https://doi.org/10.1016/0926-9851(94)90022-1

[25] Talwani, M., Worzel, J.L. and Landisman, M. (1959) Rapid Gravity Computations for Two-Dimensional Bodies with Application to the Mendocino Submarine Fracture Zone. Journal of Geophysical Research, 64, 49-59. https://doi.org/10.1029/JZ064i001p00049

[26] Talwani, M. and Heirtzler, J.R. (1964) Computation of Magnetic Anomalies Caused by Two Dimensional Structures of Arbitrary Shape. In: Parks, G.A., Ed., Computers in the Mineral Industries, Part 1: Stanford University Publications, Geological Sciences, 9, 464-480.

[27] Aboud, E., El-Masry, N., Qaddah, A., Alqahtani, F. and Moufti, M.R.H. (2015) Magnetic and Gravity Data Analysis of Rahat Volcanic Field, El-Madinah City, Saudi Arabia. NRIAG Journal of Astronomy and Geophysics, 4, 154-162. https://doi.org/10.1016/j.nrjag.2015.06.006

[28] Clark, D.A. and Emerson, D.W. (1991) Notes on Rock Magnetization Characteristics in Applied Geophysical Studies. Exploration Geophysics, 22, 547-555. https://doi.org/10.1071/EG991547

[29] Hunt, C.P., Moskowitz, B.M. and Banerjee, S.K. (1995) Magnetic Properties of Rocks and Minerals. In: Ahrens, T.J., Ed., Rock Physics and Phase Relations-A Handbook of Physical Constants, Vol. 3, Wiley, Hoboken.

[30] Stern, R.J. (1985) The Najd Fault System, Saudi-Arabia and Egypt: A Late Precambrian Rift-Related Transform System? Tectonics, 4, 497-511.

https://doi.org/10.1029/TC004i005p00497

[31] Sultan, M., Becker, R., Arvidson, R.E., Shore, P., Stern, R.J., Elalfy, Z. and Attia, R.I. (1993) New Constraints on Red-Sea Rifting from Correlations of Arabian and $\mathrm{Nu}$ bian Neoproterozoic Outcrops. Tectonics, 12, 1303-1319. https://doi.org/10.1029/93TC00819

[32] Abuzied, H.T. (1984) Geology of the Wadi Hamrawin Area, Red Sea Hills, Eastern Desert, Egypt. Ph.D. Thesis, University of South Carolina, Columbia.

[33] Farrag, A.A. (2007) On the Groundwater Assessment and Management in Wadi El Assiuti, Eastern Desert, Egypt. The 5 th International Conference, on the Geology of Africa, Assiut-Egypt, October 2007, ii-15-ii-48.

[34] Mohamed, A., Sultan, M., Ahmed, M. and Yan, E. (2014) Quantifying Modern Re- 
charge to the Nubian Sandstone Aquifer System: Inferences from GRACE and Land Surface Models. American Geophysical Union, Fall Meeting 2014, Abstract ID: G23A-0465.

[35] Mohamed, A., Sultan, M., Yan, E., Ahmed, M., Sturchio, N. and Ahmed, E. (2015) Towards a Better Understanding of the Hydrologic Setting of the Nubian Sandstone Aquifer System: Inferences from Groundwater Flow Models, Cl-36 Ages, and GRACE Data. American Geophysical Union, Fall Meeting 2015, Abstract ID: A11E-0095.

[36] Mohamed, A., Sultan, M., Ahmed, M., Yan, E. and Ahmed, E. (2017) Aquifer Recharge, Depletion, and Connectivity: Inferences from GRACE, Land Surface Models, and Geochemical and Geophysical Data. GSA Bulletin, 129, 534-546. https://doi.org/10.1130/B31460.1

[37] Mohamed, A. (2019) Hydro-Geophysical Study of the Groundwater Storage Variations over the Libyan Area and Its Connection to the Dakhla Basin in Egypt. Journal of African Earth Sciences, 157, Article ID: 103508.

https://doi.org/10.1016/j.jafrearsci.2019.05.016

[38] Mohamed, A. (2020) Gravity Based Estimates of Modern Recharge of the Sudanese Area. Journal of African Earth Sciences, 163, Article ID: 103740. https://doi.org/10.1016/j.jafrearsci.2019.103740

[39] Mohamed, A. (2020) Gravity Applications in Estimating Themass Variations in the Middle East: A Case Study from Iran. Arabian Journal of Geosciences, 13, Article NO. 364. https://doi.org/10.1007/s12517-020-05317-7

[40] Mohamed, A. (2020) Gravity Applications to Groundwater Storage Variations of the Nile Delta Aquifer. Journal of Applied Geophysics, 182, Article ID: 104177. https://doi.org/10.1016/j.jappgeo.2020.104177

[41] Mohamed, A. (2020) Time-Lapse Gravity Monitoring of Groundwater of the Sinai Peninsula. International Journal of Earth Science and Geophysics, 6, 40. https://doi.org/10.35840/2631-5033/1840

[42] Hesse, K.H., Hissese, A., Kheir, O., Schnacker, E., Schneider, M. and Thorweihe, U. (1987) Hydrogeological Investigations in the Nubian Aquifer System, Eastern Sahara. In: Kilitzsch, E. and Schranck, E., Eds., Research in Egypt and Sudan, Dietrich Reimer, Berlin, 397-464.

[43] Sturchio, N.C., Arehart, G.B., Sultan, M., Sano, Y., Abo Kamar, Y. and Sayed, M. (1996) Composition and Origin of Thermal Waters in the Gulf of Suez Area, Egypt. Applied Geochemistry, 11, 471-479.

[44] RIGW (1993) Hydrogeological Map of Egypt, Asyuti Sheet. Research Institute for Groundwater, Academy of Scientific Research and Technology, Cairo. 